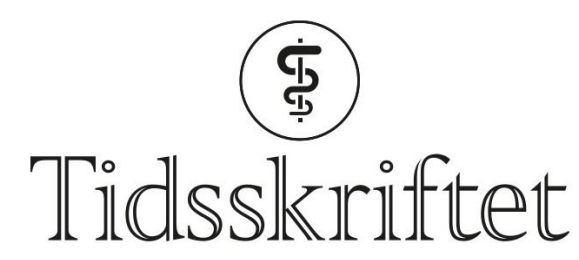

DEN NORSKE LEGEFORENING

\title{
Aina Schiøtz
}

MINNEORD

ANNE KVEIM LIE

GURI RøRTVEIT

KRISTINE LILLESTØL

ØIVIND LARSEN

OLE GEORG MOSENG

CHRISTOPH GRADMANN

MAGNUS VOLLSET

KETIL SLAGSTAD

PER HAAVE

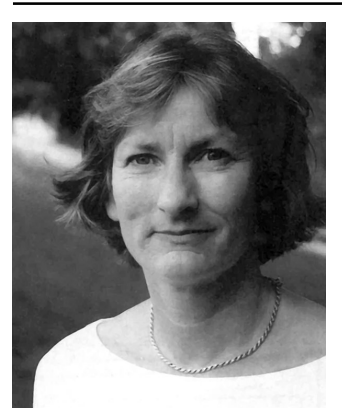

Foto: Nina Husom

Professor Aina Schiøtz døde 73 år gammel lørdag 31. oktober, etter lang tids sykdom. Vi har mistet en kjær og kunnskapsrik kollega og en sjelden brobygger mellom medisin og historiefaget.

Aina spilte en sentral rolle i forskning på kvinnehistorie og sosialhistorie - men først og fremst på medisin-og helsehistorie. Allerede i hovedfagsoppgaven Prostitusjonen i Kristiania 1870-189o fattet hun interesse for medisin og helse i historien. I perioden 1982-89 ledet hun Sekretariatet for kvinneforskning ved Norges allmennvitenskapelige forskningsråd. 
Smaken på videre forskning fikk Aina da Legeforeningens likestillingsutvalg ba henne bidra til hundreårsjubileet for uteksamineringen av Marie Spångberg som Norges første kvinnelige lege. Møtet med historieinteresserte kvinnelige leger ble avgjørende for veivalget. Et engasjement ved Legekårsundersøkelsen, forløperen til LEFO -

Legeforskningsinstituttet, og en stipendiatperiode ved Institutt for helseadministrasjon ved Universitetet i Oslo resulterte i en avhandling om distriktslegenes historie, som hun forsvarte for doktorgraden i 2000 og utga som bok i 2003 med tittelen Doktorendistriktslegenes historie 1900-1984. Samme år kom tobindsverket om det offentlige helsevesenets 400-årige historie, med Aina som redaktør og forfatter av det ene bindet. Hun var da tilknyttet Institutt for allmenn- og samfunnsmedisin ved Universitetet i Oslo, der hun også påbegynte postdoktorarbeidet om fremveksten av rettsmedisinen.

I 2005 ble hun professor i medisinsk historie ved Institutt for global helse og samfunnsmedisin i Bergen. Hun utvidet stadig sitt medisinhistoriske interessefelt og var en entusiastisk formidler gjennom utallige foredrag og artikler. Kronen på verket kom $\mathrm{i}$ 2017 med boka Viljen til liv. Bokas betydning kan knapt overdrives. Uten lærebok, intet fagfelt, blir det ofte sagt. Men dette er ikke bare en lærebok, dette er også et rikt oppslagsverk for alle som er interessert i medisin- og helsehistorie.

Aina bygget bro mellom medisin og historie, mellom leger og faghistorikere. Hun deltok i mange bokkomiteer og var en sjenerøs og konstruktiv leser av manus for kolleger. På tross av sviktende helse var Aina helt til våren 2020 en vesentlig bidragsyter i to store medisinhistoriske forskningsprosjekter. Sist, men ikke minst var hun en vedvarende støtte, både faglig og personlig, for mange av oss som ble interessert i medisinhistorie. Raust bød hun både på seg selv og sin kunnskap i møte med historieinteresserte leger og med historikere med interesse for medisin- og helsehistorie. Vi er mange som har hatt glede av hennes trillende latter, smittende entusiasme og enorme sjenerøsitet.

En ruvende skikkelse i norsk medisinsk historie er borte. Men tekstene hennes vil leve videre - og inspirere stadige nye mennesker med interesse for helse- og medisinhistorie.

Publisert: 14. desember 2020. Tidsskr Nor Legeforen. DOI: 10.4045/tidsskr.20.0900

(C) Tidsskrift for Den norske legeforening 2020. Lastet ned fra tidsskriftet.no 